でてのような臨林的問題点に対応していけるよう検討を 重ねたい.

\section{2. 放医研陽子線治療の現状}

放射線医学総合研究所

○岡本 良・坂下邦雄・熊谷和正

柴山晃一・岡崎 実

放射線医学総合研究所 (以後放医研) では，1979年10 月より医用サイクロトロンによる陽子線治療を開始し た. 陽子線のエネルギーは現在 $70 \mathrm{MeV}$ で, 飛程は約 40 $\mathrm{mm}$ である. 陽子線治療は, Bragg Peak に由来する優 れた線量分布を有効に使用することにより，治療効果の 向上が充分期待できる.

治療装置には，線量分布を有効に使用できるよう，

Bragg Peak を広げるレンジモデュレータ，不整形照射 野を得るための 2 次元スポット・スキャニング，線量分 布の徴調整を行うための水, ガムベース, ラテックス寒 天などボーラスの作成・開発を行った。

\section{3. リニアック $10 \mathrm{MV} \mathrm{X}$ 線照射室の漏洩中性子線の遮}

\section{蔽について（第 2 報）}

群馬大学医学部附属病院中央放射線部

○宮澤康志・高橋一宇・小山一郎

松原国夫 $\cdot$ 大竹英則 $\cdot$ 五十風均

佐藤貞男・浦野晴哉

前回，本研究発表会に扣いて当施設における漏洩中性 子対策を行うライナック 2 号機について発表したが, 良好な結果が得られたので報告する。今回設置された LMR-15 は，従来のタングステンターゲットを銅に変え， 照射室は一号機に比べやや狭くなったあのの，迷路中間 に10\%ホウ菜入りポリエチンン $3 \mathrm{~cm}$ 愿のドアを設け， 外部ドアも従来の $\mathrm{Pb} 6 \mathrm{~mm}$ に加え同様の $3 \mathrm{~cm}$ 厚ポり エチンンを使用し，迷路中間及び照射室と迷路の境に下 がり壁を設置した. その結果漏洩中性子線量は LMR-13 に比べ約1/40亿減少した。一方ターゲットを銅に変えた ことによる出力線圕もさほど見られず，現在 $3 \mathrm{~Gy} /$ 分で 稼動中である.

質問 STUDSVIK220D の雑音による影響は？われ われが, ある病院のリニアック施設において同測定器を 用いて，中性子線量測定を行った結果，電子ビームを出 さずに，マイクロ波のみ稼動させる状態で，測定器の針 が振り切れてしまった. とれは，マイクロ波（クライス トロンのパルス）による雑音と考えられる. 群馬大学に おいては，われわれ之同様な雑音による影響はなかった のですか？ また；影響があったとしたら，どのように 防いだのですか？
答 ノイズによる影響は本測定においては出ていな い.

24. 医療用直線加速器の保守管理について

放射線医学総合研究所病院部

○坂下邦雄・岡崎 実・熊谷和正

岡本 良・柴山晃一

化学療法研究所附属病院 林 太郎

当施設では三菱電機社製 ML15M II型直線が速器を 1973年より使用して以来 9 年間経過した。乙の間の治療 装置の稼動状況乙保守管理について報告する。放射線治 療は連続して長期間行うため治療装置を故障により運転 休止することはできるだけ未然に防がねばならない。故 障率を減少させるには装置の環境状態を良くし，装置の 日々の点検と運転記録に基ずいた故障原因に対する解析 を行い，故障に対する的確な判断をするならば短時間に 修理を行い，運転再開できるであるう，当施設では応急 修理ができるように予備部品を保管している：てれらの 対策をすることにより 9 年間の平均稼動率は $98.5 \%$ とな った.

\section{RI 検查技術 I}

座長 早瀬武雄 (茅ケ崎市立病院)

\section{ECT 検査の臨床}

千葉県がんセンター核医学䛦療科

○木下富士美・小圷正木

SPECT 専用装置（GCA-70A）を導入後，1年半を経 過し, 約 2,000 件の臨床使用経験により得た 2,3 の技 術的知見と臨床例を供覽して報告した. Conventionalimage/ECT 検査比は約 $55 \%$ で1, 452(人)/ 1 年 (1982年 6 月現在)の患者に実施した. ECT 装置は本格的な開発の 日も浅く, 検出器回転時の安全性は, 本装置に限らず, 他の疾療検査装置に比べまだ低いようで，検査施行時の 安全確認が大切なことである.また, 被検者の臨床状態 にあった资位での完全固定の択選む必要である. ECT検 查の利点としては，通常の検查に引き続いての検查が可 能で, 病巣の局在や進展, 他蔵器との重なり部位での獄 断に，上り有用性のある検查手段と考劣る。

26. ${ }^{201} \mathrm{~T} 1$ による下肢筋肉血流スキャン

埼玉医科大学附属病院放射線科

○小川 清・宮野良介 加藤知明 ・ 関 守雄

${ }^{201} \mathrm{Tl}$ が下肢虚血性疾患の診断に用いられているが，正 常分布に対しての報告は少ない。:そてで ${ }^{201} \mathrm{Tl}$ 全身スキ ヤンを負荷別 (At rest, Ergo meter, Tread mill) に Early, Delayed scan を行い, ROI 作成し，その分布を 
検討した。

全身分布に対する比率では，安静時に比べて大煺，下 腿部之も2.0〜2.5倍集積が強まった. ErgoとTreadは， 大腿部で $\mathrm{E}>\mathrm{T}$ ，下腿部で $\mathrm{E}<\mathrm{T}$ ，を示し運動量のちがい を示した。 それに伴い，Delayedでは集積の高い部位は 変化せず，集積の少ない部位は上昇した，ROI 設定し， そのカウント比を得るととによって, 正常 ${ }^{201} \mathrm{Tl}$ 下肢筋 肉血流分布を負荷方法別に把握でき，診断に有用であっ た。

\section{7. 抗体チューブを用いた $\mathrm{T}_{3}$ 測定系の検討}

自治医科大学附属病院 RI 測定室 ○佐藤久子・長井房子

試験管固相法による SPAC $T_{3}$ KIT を使用する機会を 得，基礎的並びに臨床的検討を行い以下の成績をえた。 (1)標準曲線は $37^{\circ} \mathrm{C} 2$ 時間のインキュベーションにより急 唆な安定した曲線が得られた。(2)測定内変動は 4.8〜8.9 $\%$, 測定間変動は5. 7 9.3\% と良好で, 希釈・回収試験 あ満足できる成績であった。（3) T 3 ・RIAKIT Iとの比較 では相関係数 $r=0.988$ と極めて高い正の相関を認めた。 (4)本法で測定した血中 $T_{3}$ 值は正常者で平均 $122 \mathrm{ng} / \mathrm{d} l$, 甲状腺機能庁進症で $258 \mathrm{ng} / \mathrm{d} l$, 低下症で $55 \mathrm{ng} / \mathrm{d} l$ であ った．本法は BF 分離に遠心操作を要さず，迅速かつ簡 便に行え，感度，精度，再現性等の指標を含めて臨床上 の有用性が想定される.

28. 血中 estradiol $\left(\mathrm{E}_{2}\right)$ radioimmunoassay の吟味 帝京大学医学部附属溝口病院核医学 ○喜多村道男・滝口千恵子・冨吉真奈美 島貫 通・新田康雄

従来は，ベーターエミッターである ${ }^{3} \mathrm{H}$ による $\mathrm{E}_{2}$ の 測定であった，加えて血中濃度が低いためセファデック スカラムによるカラムクロマトグラフィなどの複雑な前 処理が必要であった．近年， ${ }^{125} \mathrm{I}$ を用い前処理む比較的 簡便な方法が開発され，本法を日常検査として導入する にあたり若干の検討を行い， $2 ， 3$ の知見を得たので報 告した。すなわち精密度については日常検査として支障 の少ないととがわかったが，主として，添加回収試験で 正確度が保障されていないととが示唆された. われわれ は前処理操作である溶媒抽出および脱脂肪操作に起因す るあのと考えた。

\section{RI 検查技術 II}

座長 萩原和男（日大板橋病院）

\section{9. 脳血流装置（ $\boldsymbol{\gamma}$-CBF）の使用経験}

帝京大学医学部附属病院放射線科核医学検査窒 ○池田信子・新尾泰男
河䇠雅宏・高田賢二

$\gamma$-CBF 测定装置 RRG526 を使用する機会を得たので 検討を加え使用経験を報告する. 正常值は $\mathrm{INH}$ 法F1= $74.9 \pm 9.62 \mathrm{ml} / 100 \mathrm{~g} / \mathrm{min}, \mathrm{ISI}=50.2 \pm 9.5, \mathrm{~W}_{1}=35.9 \pm$ $5.6 \%, \mathrm{FFI}=0.733 \pm 0.06, \mathrm{~K} 2=0.097 \pm 0.01$ となり, IV 法ではやや高いが，近い值が得られた.コリメータ の空中感度曲線より, 半洒層は $1.3 \mathrm{~cm}, 1.1 \mathrm{~cm}$ で臨床 データより感度は $0.216 \mathrm{cps} / \mu \mathrm{Ci}$ であった。

正常例での同一例 IV 法/INH 法の比較, 再現性など, ややバラッキが認められたが， $\gamma-\mathrm{CBF}$ の方法論自体の性 格から手軽な操作性, 非侵襲性を考慮してスクリーニン グとして利用可能と思われる.

質問 (1)頭部外に出た検出器があった場合, そのデー タはどのようにしているか。

(2)灰白質の計算ができないととを経験しているが，も しあったらそのデータはどのようにしているか.

答 (1)脳実質外へ検出器を当ていた場合のデータの除 去は，事後ではできない。唯し，位置決め後 $\mathrm{x}-\mathrm{p}$ をとり 確認しているので，そのような現象は防げる。また，他 社に比較して, $7 \mathrm{ch} / \mathrm{side}$ と検出器が少なく, 位置決め の再現性は容易であり，検出器数が多すぎての設定不良 という現象はない。

\section{0. シンチカメラの均一性補正回路（DUFC）の特性に ついて}

\author{
自治医科大学附属病院中央放射線部 \\ ○川村義文・黑田順平・鐮田 斉 \\ 神山辰彦・羽仁生大輔
}

シンチカメラには，装置固有な不均一性を補正するた めに補正回路を利用しているものがある．との補正回路

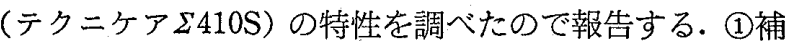
正を行うことで検出感度が低下する．補正ウィンド $20 \%$ で $9 \%$ 感度が低下する. (2)補正ウィンドと検査ウィンド は同じ幅であることがよく，20\%の時最す均一性がよ い. 均一性の評価は，相対的不均一度と最大偏差で表わ した．前者はX軸で $0.018 ， \mathrm{Y}$ 軸で $0.023 て ゙ あ り ，$ 後者は $\mathrm{X}$ 軸で士 $10.0 \%$ ，Y軸で士10.4\%である. (3) 1 本の光電 子增倍管の感度が $80 \%$ 低下しても補正を行うことができ る. その時の検出感度は，正常時に比べ20\%低下する。

31. 心臓疾患におけるコンピュータ算出データの信頼性 の技術的評価（第 2 報）

東京医科大学霞浦病院放射線科

○宮内兼義・棣沢 敦・佐藤 斉 梅田和夫・伊藤仲一・富所忠彦 中島箇・高根重信 